\title{
Effects of Fertilizer P Additions on Available P, Microbial Biomass - P and Phosphatase Enzyme Activity under Maize (Zea mays L.) in P Rich Acid Soils
}

\author{
T. Lavanya Bai, B.C. Dhananjaya*, M. Dinesh Kumar and K.T. Gurumurthy
}

Department of Soil Science \& Agricultural Chemistry, College of Agriculture, University of Agricultural and Horticultural Sciences, Shivamogga 577204, Karnataka, India

*Corresponding author

\section{A B S T R A C T}

\begin{tabular}{|l|}
\hline K e y w o r d s \\
Phosphorus, Zea \\
$\begin{array}{l}\text { mays L., PSB, } \\
\text { Maize, Seed } \\
\text { treatment, P fraction }\end{array}$ \\
\hline Article Info \\
\hline $\begin{array}{l}\text { Accepted: } \\
\text { 12 August } 2018 \\
\text { Available Online: } \\
\text { 10 September } 2018\end{array}$ \\
\hline
\end{tabular}

\section{Introduction}

Holistic understanding of $\mathrm{P}$ dynamics from soil to plant is of increased interest for optimizing $\mathrm{P}$ management and improving $\mathrm{P}$ use efficiency, aiming at reducing composition of chemical $\mathrm{P}$ fertilizer, maximizing exploitation of the biological potential of roots/ rhizosphere processes for efficient mobilization and acquisition of soil $\mathrm{P}$ by plants. Microbial solubilization of inorganic $P$ compounds is of great economic importance in plant nutrition. Soil microorganisms like $\mathrm{P}$
A field experiment was carried out at college of Agriculture, Navile, Shivamogga during kharif 2016 to study Effects of fertilizer P additions on available P, microbial biomass - P and phosphatase enzyme activity under maize (Zea mays L.) in P rich acid soils with and without seed treatment. The levels of $\mathrm{P} @ 0,30,45,60$ and $75 \mathrm{~kg} \mathrm{P}_{2} \mathrm{O}_{5}$ per ha ${ }^{-1}$ with or without PSB seed treatment was tried in a randomized complete block design with three replications and eleven treatments. The results of the experiment indicated that seed treatment with PSB and higher levels of $\mathrm{P}$ significantly higher values of available $\mathrm{P}$, id-P and Ca-P status in soil were recorded with $75 \mathrm{~kg} \mathrm{P}_{2} \mathrm{O}_{5}$ per ha ${ }^{-1}$ with $\mathrm{PSB}$ seed treatment at different crop growth stages. Higher values of Al-P, Fe-P, reductant-P, without PSB seed treatments. Treatment receiving $75 \mathrm{Kg} \mathrm{P}_{2} \mathrm{O}_{5}$ per ha ${ }^{-1}$ without PSB seed treatment recorded higher Al-P, Fe-P, reductant-P, occluded-P, organic-P and total-P fraction values. The occurrence of forms of $\mathrm{P}$ were in the order of total $\mathrm{P}>$ organic $\mathrm{P}>$ reductant soluble $\mathrm{P}>>\mathrm{Fe}-\mathrm{P}>\mathrm{Al}-\mathrm{P}>$ occluded $\mathrm{P}>$ saloid $\mathrm{P}>\mathrm{Ca}-\mathrm{P}$. 
fertilizers. Such native built-up P can become a constant source of $\mathrm{P}$ to the crops if explored properly by using PSB.

\section{Materials and Methods}

A field experiment was conducted at college of Agriculture, Navile, Shivamogga, in Karnataka state of India. Experiment comprised of 11 fertilizer treatment combinations and replicated thrice in Randomized Complete Block Design (RCBD), with Maize (Zea mays L.) test crop. The FYM at 10 tons ha $^{-1}$ was applied uniformly across all the treatments two weeks before sowing. Also, before sowing seeds were treated with the Phosphorus solubilizing bacteria (PSB) (Bacillus megatherium) (375 g $\mathrm{ha}^{-1}$ ), shade dried. Seed treatment is done as per the treatment details to $\mathrm{T}_{3}, \mathrm{~T}_{5}, \mathrm{~T}_{7}, \mathrm{~T}_{9}$ and $\mathrm{T}_{11}$. The different levels of $\mathrm{P}_{2} \mathrm{O}_{5}$ with and without PSB seed treatment were tried to treatments at the rate of $30 \mathrm{~kg} \mathrm{ha}^{-1}$ to $\mathrm{T}_{6}$ and $\mathrm{T}_{7}, 45 \mathrm{~kg} \mathrm{ha}^{-1}$ to $\mathrm{T}_{8}$ and $\mathrm{T}_{9}, 60 \mathrm{~kg} \mathrm{ha}^{-1}$ to $\mathrm{T}_{10}$ and $\mathrm{T}_{11}$. The recommended doses of fertilizers were applied @ 150: 75: $40 \mathrm{~N}, \mathrm{P}_{2} \mathrm{O}_{5}$, and $\mathrm{K}_{2} \mathrm{O}$ $\mathrm{kg} \mathrm{ha}^{-1}$. At the time of sowing 50 percent $\mathrm{N}$ and $\mathrm{K}$ and entire $\mathrm{P}$ were applied. Remaining 50 percent of $\mathrm{N}$ and $\mathrm{K}$ were applied at 30 days after sowing (DAS) as top dressing. The treatment details are as follows $\mathrm{T}_{1}$ : control (No fertilizer), $\mathrm{T}_{2}: \mathrm{RDF}, \mathrm{T}_{3}: \mathrm{T}_{2}+\mathrm{PSB}, \mathrm{T}_{4}: \mathrm{RD}$ $\mathrm{N} \& \mathrm{~K}$ only, $\mathrm{T}_{5}: \mathrm{T}_{4}+\mathrm{PSB}, \mathrm{T}_{6}: \mathrm{RD} \mathrm{N} \& \mathrm{~K}+$ $30 \mathrm{~kg} \mathrm{P}_{2} \mathrm{O}_{5}$ ha $^{-1}$ as DAP, $\mathrm{T}_{7}: \mathrm{T}_{6}+\mathrm{PSB}, \mathrm{T}_{8}$ : RD $\mathrm{N} \& \mathrm{~K}+45 \mathrm{~kg} \mathrm{P}_{2} \mathrm{O}_{5} \mathrm{ha}^{-1}$ as DAP, $\mathrm{T}_{9}: \mathrm{T}_{8}+$

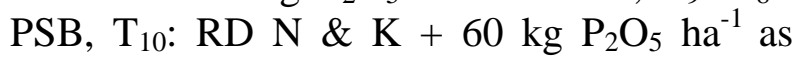
DAP, $\mathrm{T}_{11}: \mathrm{T}_{10}+\mathrm{PSB}$.

The DAP fertiliser is used as P source. Seed treatment with PSB (Bacillus megatherium) $\left(375 \mathrm{~g} \mathrm{ha}^{-1}\right)$ was made by shade drying. Initial characterization of soil for the experimental site indicated that soil was acidic in reaction $(\mathrm{pH}-5.58)$ with low organic carbon status $\left(4.8 \mathrm{~g} \mathrm{~kg}^{-1}\right)$ with sandy loam texture (Typic haplustalf). Available phosphorus was extracted from the soils using Bray's No.1 extractant $\left(0.03 \mathrm{~N} \mathrm{NH}_{4} \mathrm{~F}+0.025 \mathrm{~N} \mathrm{HCl}\right)$ and the concentration was determined by spectrometer (Jackson, 1973). The soil was medium in nitrogen $\left(439 \mathrm{~kg} \mathrm{ha}^{-1}\right)$, high in $\mathrm{P}$ status $\left(94.60 \mathrm{~kg} \mathrm{ha}^{-1}\right)$ and high in available $\mathrm{K}$ status $\left(376.32 \mathrm{~kg} \mathrm{ha}^{-1}\right)$. Microbial P (Pmic) was determined by fumigating soil samples with chloroform (CHCls) and measuring the inorganic $\mathrm{P}(\mathrm{Pi})$ released by lysis of microbial biomass (Brookes et al., 1982). The acid phosphatase activities were estimated as per the procedure given by Eivazi and Tabatabai (1977). The initial status of total P, microbial biomass $\mathrm{P}$ and phosphatase enzyme activity were $284.25 \mathrm{mg} \mathrm{kg}^{-1}, 29.58 \mu \mathrm{g} \mathrm{g}^{-1}$ soil and $20.64 \mu \mathrm{g}$ PNP h$^{-1} \mathrm{~g}^{-1}$ soil, respectively.

\section{Results and Discussion}

\section{Effect of $P$ levels and PSB seed treatment on microbial biomass $\mathbf{P}$ in soil at different intervals in maize}

The values of microbial biomass $\mathrm{P}$ in soil varied at all the crop stages due to various levels of P and PSB seed treatment. At all the stages, higher values were recorded in $\mathrm{P}$ levels with PSB seed treatment than levels of only P application. The values of microbial biomass $\mathrm{P}\left(\mu \mathrm{g} \mathrm{g}^{-1}\right.$ soil $)$ decreased with crop growth. At 30 DAS, among the treatments, $T_{3}$ (RDF with PSB seed treatment) recorded highest microbial biomass $\mathrm{P}$ (396.23 $\mu \mathrm{g} \mathrm{g}^{-1}$ soil) followed by $\mathrm{T}_{2}(\mathrm{RDF})$ treatment with 277.78 $\mu \mathrm{g} \mathrm{g}^{-1}$ soil and were significantly higher compared to rest of the treatments. Lowest microbial biomass $\mathrm{P}\left(74.57 \mu \mathrm{g} \mathrm{g}^{-1}\right.$ soil $)$ was found in control $\left(\mathrm{T}_{1}\right)$ followed by $\mathrm{T}_{4}$ treatment (Recommended NK only) (96.80 $\mu \mathrm{g} \mathrm{g}^{-1}$ soil). Similar trend of variation in the microbial biomass $\mathrm{P}$ was observed at 60 and 90 DAS and at harvest of maize. At 60 and 90 DAS, treatment $\mathrm{T}_{3}\left(75 \mathrm{~kg} \mathrm{P}_{2} \mathrm{O}_{5} \mathrm{ha}^{-1}\right.$ as DAP with PSB seed treatment) recorded significantly higher microbial biomass P (144.33 and 89.49 
$\mu \mathrm{g} \mathrm{g}^{-1}$ soil, respectively). Lowest values of microbial biomass $\mathrm{P}$ in soil were recorded in $\mathrm{T}_{1}$ (control) treatment (58.15 and $47.69 \mu \mathrm{g} \mathrm{g}^{-1}$ soil, respectively) followed by $\mathrm{T}_{4}$ (recommended NK only) with values of 66.35 and $49.36 \mu \mathrm{g} \mathrm{g}^{-1}$ soil, respectively. Significant decrease in microbial biomass $\mathrm{P}$ in soil were recorded due to the application of $\mathrm{P}$ levels with or without PSB seed treatment at different intervals of maize. Even at harvest of crop, microbial biomass $\mathrm{P}$ varied due to various levels of $\mathrm{P}$ and higher values were recorded in $\mathrm{P}$ levels with $\mathrm{PSB}$ seed treatment than only $\mathrm{P}$ levels. Among the treatments, at harvest, $\mathrm{T}_{3}$ (RDF + PSB seed treatment) recorded highest microbial biomass $P$ value of (71.28 $\mu \mathrm{g} \mathrm{g}^{-1}$ soil) followed by $\mathrm{T}_{2}\left(65.18 \mu \mathrm{g} \mathrm{g}^{-}\right.$ ${ }^{1}$ soil) and were significantly higher compared to control $\left(\mathrm{T}_{1}\right)\left(9.76 \mu \mathrm{g} \mathrm{g}^{-1}\right.$ soil) and no $\mathrm{P}$ application $\left(\mathrm{T}_{4}\right)\left(16.68 \mu \mathrm{g} \mathrm{g}^{-1}\right.$ soil). At harvest also, significant decreases in microbial biomass $\mathrm{P}$ in soil were recorded due to the application of $\mathrm{P}$ levels with or without PSB seed treatment only after treatment $\mathrm{T}_{6}(30 \mathrm{~kg}$ $\mathrm{P}_{2} \mathrm{O}_{5}$ ha $^{-1}$ as DAP).

Effect of $P$ levels and PSB seed treatment on phosphatase enzyme activity in soil at different intervals in maize

Phosphatase enzyme activity $\left(\mu \mathrm{g}\right.$ PNP $\mathrm{h}^{-1} \mathrm{~g}^{-1}$ soil) in soil varied at all the stages due to various levels of P and PSB seed treatment. At all the stages, higher values were recorded in $\mathrm{P}$ levels with PSB seed treatment than only P levels and the enzyme activity increased with crop growth. At 30 DAS, among the treatments, $\mathrm{T}_{3}$ (RDF with PSB seed treatment) recorded highest phosphatase enzyme activity (89.28 $\mu \mathrm{g}$ PNP $\mathrm{h}^{-1} \mathrm{~g}^{-1}$ soil) followed by $\mathrm{T}_{2}$ (RDF) treatment with $87.12 \mu \mathrm{g}$ PNP $\mathrm{h}^{-1} \mathrm{~g}^{-1}$ soil) were significantly higher compared to rest of the treatments. Lowest phosphatase enzyme activity in maize was found in (30.94 $\mu \mathrm{g}$ PNP $\mathrm{h}^{-1} \mathrm{~g}^{-1}$ soil) control $\left(\mathrm{T}_{1}\right)$ followed by $\mathrm{T}_{4}$ (Recommended NK only) (43.50 $\mu \mathrm{g}$ PNP $\mathrm{h}^{-1} \mathrm{~g}^{-1}$ soil) treatment. Similar trend of variation in the phosphatase enzyme activity was observed at 60 and 90 DAS and at harvest of maize. At 60 and 90 DAS, treatment $\mathrm{T}_{3}$ (75 $\mathrm{kg} \mathrm{P}_{2} \mathrm{O}_{5} \mathrm{ha}^{-1}$ as DAP with PSB seed treatment) recorded significantly higher phosphatase enzyme activity $\left(86.09\right.$ and $86.86 \mu \mathrm{g} \mathrm{PNP} \mathrm{h}^{-1}$ $\mathrm{g}^{-1}$ soil). Lowest values of phosphatase enzyme activity in soil were recorded in $\mathrm{T}_{1}$ (control) treatment (23.22 and $32.04 \mu \mathrm{g}$ PNP $\mathrm{h}^{-1} \mathrm{~g}^{-1}$ soil, respectively). Significant decrease in phosphatase enzyme activity in soil was recorded due to the application of $\mathrm{P}$ levels with or without PSB seed treatment at different intervals of maize. Even at harvest of crop, phosphatase enzyme activity varied due to various levels of $\mathrm{P}$ and higher values were recorded in $\mathrm{P}$ levels with $\mathrm{PSB}$ seed treatment than only $\mathrm{P}$ levels. Among the treatments, at harvest, $\mathrm{T}_{3}$ (RDF + PSB seed treatment) recorded highest phosphatase enzyme activity value of ( $\mu \mathrm{g}$ PNP h${ }^{-1} g^{-1}$ soil) followed by $T_{2}$ (RDF) (113.34 $\mu \mathrm{g}$ PNP h ${ }^{-1} \mathrm{~g}^{-1}$ soil) and were significantly higher compared to other treatments. Lowest was recorded in control $\left(\mathrm{T}_{1}\right)\left(73.39 \mu \mathrm{g} \mathrm{PNP} \mathrm{h}^{-1} \mathrm{~g}^{-1}\right.$ soil) followed by no $\mathrm{P}$ application $\left(\mathrm{T}_{4}\right)\left(79.83 \mu \mathrm{g} \mathrm{PNP} \mathrm{h}^{-1} \mathrm{~g}^{-1}\right.$ soil) treatment.

Effect of $P$ levels and PSB seed treatment on available $P$ status in soil at different intervals in maize

Available $\mathrm{P}$ status in soil at all the stages varied significantly due to various levels of $\mathrm{P}$ with and without PSB treatment. At all the stages, higher values were recorded in P levels with PSB seed treatment than only P levels. Among the treatments, application of $75 \mathrm{~kg}$ $\mathrm{P}_{2} \mathrm{O}_{5} \mathrm{ha}^{-1}$ as DAP with PSB seed treatment $\left(\mathrm{T}_{3}\right)$ recorded highest available $\mathrm{P}$ values $\left(189.05,170.05,148.06\right.$ and $134.68 \mathrm{~kg} \mathrm{ha}^{-1}$, at $30,60,90$ DAS and at harvest, respectively) followed by application of $75 \mathrm{~kg} \mathrm{P}_{2} \mathrm{O}_{5} \mathrm{ha}^{-1}$ as DAP $\left(T_{2}\right)$ compared to other treatments at different crop growth stages. 
Table.1 Effect of P levels and PSB seed treatment on microbial biomass P and phosphatase enzyme activity in soil at different intervals in maize

\begin{tabular}{|c|c|c|c|c|c|c|c|c|c|c|c|c|}
\hline \multirow[t]{2}{*}{ Treatments } & \multicolumn{4}{|c|}{$\begin{array}{l}\text { Microbial biomass phosphorus } \\
\qquad\left(\mu \mathrm{g} \mathrm{g}^{-1} \text { soil }\right)\end{array}$} & \multicolumn{4}{|c|}{$\begin{array}{l}\text { Phosphatase enzyme activity } \\
\left(\mu \mathrm{g} P \mathrm{P} \mathrm{h}^{-1} \mathrm{~g}^{-1} \text { soil }\right)\end{array}$} & \multicolumn{4}{|c|}{$\begin{array}{l}\text { A vailable } \mathrm{P}_{2} \mathrm{O}_{5} \\
\quad\left(\mathrm{~kg} \mathrm{ha}^{-1}\right)\end{array}$} \\
\hline & $\begin{array}{c}30 \\
\text { DAS }\end{array}$ & $\begin{array}{c}\text { 60 } \\
\text { DAS }\end{array}$ & $\begin{array}{c}90 \\
\text { DAS }\end{array}$ & Harvest & $\begin{array}{c}30 \\
\text { DAS }\end{array}$ & $\begin{array}{c}60 \\
\text { DAS }\end{array}$ & $\begin{array}{c}90 \\
\text { DAS }\end{array}$ & $\begin{array}{c}\text { Harves } \\
\mathbf{t}\end{array}$ & $\begin{array}{c}30 \\
\text { DAS }\end{array}$ & $\begin{array}{c}60 \\
\text { DAS }\end{array}$ & $\begin{array}{c}90 \\
\text { DAS }\end{array}$ & Harvest \\
\hline $\mathrm{T}_{1}$ : Control (No fertilizer) & 74.57 & 30.94 & 30.94 & 30.94 & 30.94 & 23.22 & 32.04 & 73.39 & 125.95 & 117.94 & 81.17 & 89.31 \\
\hline $\begin{array}{l}\mathrm{T}_{2}: \quad \text { Recommended } \\
\left(150: 75: 40 \mathrm{~kg} \mathrm{NP}_{2} \mathrm{O}_{5} \mathrm{~K}_{2} \mathrm{Oha}^{-1}\right)\end{array}$ & 277.78 & 87.12 & 87.12 & 87.12 & 87.12 & 82.76 & 84.23 & 113.34 & 189.05 & 170.05 & 148.06 & 134.68 \\
\hline $\mathrm{T}_{3}:$ Recommended NPK + PSB & 396.23 & 89.28 & 89.28 & 89.28 & 89.28 & 86.09 & 86.86 & 116.41 & 195.55 & 190.65 & 155.55 & 148.09 \\
\hline $\mathrm{T}_{4}$ : Recommended NK only & 96.80 & 43.50 & 43.50 & 43.50 & 43.50 & 29.00 & 34.06 & 79.83 & 112.16 & 108.03 & 104.86 & 102.29 \\
\hline $\mathrm{T}_{5}: \mathrm{T}_{4}+\mathrm{PSB}$ & 133.85 & 49.95 & 49.95 & 49.95 & 49.95 & 40.65 & 46.43 & 88.58 & 116.83 & 114.34 & 108.56 & 106.10 \\
\hline $\begin{array}{l}\mathrm{T}_{6}: \mathrm{T}_{4}+30 \mathrm{~kg} \mathrm{P}_{2} \mathrm{O}_{5} \mathrm{ha}^{-1} \\
(40 \% \text { of recommended } \mathrm{P})\end{array}$ & 135.35 & 60.39 & 60.39 & 60.39 & 60.39 & 50.50 & 57.93 & 91.33 & 138.09 & 123.58 & 110.32 & 108.39 \\
\hline $\begin{array}{l}\mathrm{T}_{7}: \mathrm{T}_{4}+30 \mathrm{~kg} \mathrm{P}_{2} \mathrm{O}_{5} \mathrm{ha}^{-1}+\mathrm{PSB} \\
(40 \% \text { of recommended } \mathrm{P})\end{array}$ & 147.89 & 64.05 & 64.05 & 64.05 & 64.05 & 52.73 & 61.08 & 98.36 & 150.68 & 141.15 & 120.88 & 112.21 \\
\hline $\begin{array}{l}\mathrm{T}_{8}: \mathrm{T}_{4}+45 \mathrm{~kg} \mathrm{P}_{2} \mathrm{O}_{5} \mathrm{ha}^{-1} \\
(60 \% \text { of recommended } \mathrm{P})\end{array}$ & 154.17 & 69.10 & 69.10 & 69.10 & 69.10 & 60.83 & 69.29 & 101.18 & 160.70 & 151.25 & 127.27 & 121.37 \\
\hline $\begin{array}{l}\mathrm{T}_{9}: \mathrm{T}_{4}+45 \mathrm{~kg} \mathrm{P}_{2} \mathrm{O}_{5} \mathrm{ha}^{-1}+\mathrm{PSB} \\
(60 \% \text { of recommended } \mathrm{P})\end{array}$ & 209.73 & 71.96 & 71.96 & 71.96 & 71.96 & 67.49 & 69.72 & 104.59 & 170.13 & 159.39 & 131.23 & 128.24 \\
\hline $\begin{array}{l}\mathrm{T}_{10}: \mathrm{T}_{4}+60 \mathrm{~kg} \mathrm{P}_{2} \mathrm{O}_{5} \mathrm{ha}^{-1} \\
(80 \% \text { of recommended } \mathrm{P})\end{array}$ & 218.11 & 76.90 & 76.90 & 76.90 & 76.90 & 68.96 & 77.45 & 107.66 & 179.11 & 168.43 & 132.09 & 128.24 \\
\hline $\begin{array}{l}\mathrm{T}_{11}: \mathrm{T}_{4}+60 \mathrm{~kg} \mathrm{P}_{2} \mathrm{O}_{5} \mathrm{ha}^{-1}+\mathrm{PSB} \\
(80 \% \text { of recommended P) }\end{array}$ & 228.26 & 82.25 & 82.25 & 82.25 & 82.25 & 77.27 & 78.33 & 111.84 & 183.31 & 175.61 & 145.32 & 131.29 \\
\hline S. Em. \pm & 39.91 & 3.12 & 3.12 & 3.12 & 3.12 & 7.20 & 4.23 & 1.49 & 14.41 & 10.49 & 10.20 & 4.08 \\
\hline C.D. $(p=0.05)$ & 119.66 & 6.69 & 6.69 & 6.69 & 6.69 & 17.52 & 9.44 & 2.14 & 45.40 & 33.06 & 32.15 & 12.04 \\
\hline
\end{tabular}


Lowest available status at all the stages was recorded in no $\mathrm{P}$ applied $\mathrm{T}_{4}$ treatment. The increased in post-harvest soil compared to initial soil and differed significantly due to the application of graded levels of phosphorus and PSB. Significantly higher (148.09 kg $\mathrm{ha}^{-1}$ ) available $\mathrm{P}$ value was found in RDF + PSB $\left(\mathrm{T}_{3}\right)$ over all other treatments. However, it was on par with $\mathrm{T}_{2}$ (RDF) and $\mathrm{T}_{11}$ (RD-N \& $\mathrm{K}+80 \% \mathrm{RD}-\mathrm{P}+\mathrm{PSB})$. The lower available $\mathrm{P}$ status (89.31 kg ha-1) was found in control $\left(\mathrm{T}_{1}\right)$ followed by RD-N \& $\mathrm{K}+\mathrm{No}-\mathrm{P}$ with and without PSB seed treatment $\left(\mathrm{T}_{4}\right.$ and $\left.\mathrm{T}_{5}\right)$ (102.29 and $106.10 \mathrm{~kg} \mathrm{ha}^{-1}$ respectively). At all the stages, higher values were recorded in $\mathrm{P}$ levels with PSB seed treatment than only P levels.

Microbial biomass $\mathrm{P}$ varied due to various levels of $\mathrm{P}$ and higher values were recorded in $\mathrm{P}$ levels with PSB seed treatment than only $\mathrm{P}$ levels (Table 1). Among the treatments, at harvest, $\mathrm{T}_{3}$ (RDF + PSB seed treatment) recorded highest microbial biomass $P$ value of (71.28 $\mu \mathrm{g} \mathrm{g}^{-1}$ soil) followed by $\mathrm{T}_{2}$ (RDF) $\left(65.18 \mu \mathrm{g} \mathrm{g}^{-1}\right.$ soil) and were significantly higher compared to control $\left(\mathrm{T}_{1}\right)\left(9.76 \mu \mathrm{g} \mathrm{g}^{-1}\right.$ soil) and no $\mathrm{P}$ application $\left(\mathrm{T}_{4}\right)\left(16.68 \mu \mathrm{g} \mathrm{g}^{-1}\right.$ soil). At harvest also, significant decreases in microbial biomass $\mathrm{P}$ in soil were recorded due to the application of $\mathrm{P}$ levels with or without PSB seed treatment only after treatment $T_{6}$ (30 kg $\mathrm{P}_{2} \mathrm{O}_{5} \mathrm{ha}^{-1}$ as DAP). Significant effects of $\mathrm{P}$ treatments with seed treatment were observed with respect to available $\mathrm{P}$, soil microbial biomass $\mathrm{P}$ (MBP) and phosphatase enzyme activity in soil at different growth stages of maize At all the crop growth stages, higher available $\mathrm{P}$ values were recorded with PSB seed treatment than only P levels. This might be due to increased availability of $P$ in soil due to higher application of $\mathrm{P}$, enhanced $P$ availability by the mineralization of organic $\mathrm{P}$ in soil by soil microorganisms and also due to the solubilization of precipitated phosphate (Chen et al., 2006). Sudhir et al., (2000) also reported that the soil available $\mathrm{P}$ increased considerably due to continuous use of $\mathrm{P}$ fertilizers along with FYM. During crop growth, specific root processes, such as the release of $\mathrm{H}^{+}$ions, also may be responsible for solubilizing the relatively insoluble $\mathrm{P}$ and residual $\mathrm{P}$ forms. Application of PSB helps in realizing $\mathrm{P}$ from native $\mathrm{P}$ as well as protecting fixation of added $\mathrm{P}$ and rendering more available $\mathrm{P}$. The variation in MBP is due to size and structure of microbial biomass which is sensitive to factors like microclimate and fertilizer. The immobilized $\mathrm{P}$ by microbes will be released gradually, thus, protecting the released $\mathrm{P}$ from physic-chemical adsorption reaction. This indicates the immobilized $\mathrm{P}$ was released, thus, adding to the available $\mathrm{P}$ in the soil as also reported by Logah et al., (2010). Application of fertilizer and manures stimulate more plant root growth and lead to more and more root exudates resulting in stimulated biological activity and thus increasing the soil microbial biomass-C, N and $\mathrm{P}$.

Variation in the phosphatase enzyme activity was observed at 60 and 90 DAS and at harvest of maize. At 60 and 90 DAS, treatment $\mathrm{T}_{3}\left(75 \mathrm{~kg} \mathrm{P}_{2} \mathrm{O}_{5} \mathrm{ha}^{-1}\right.$ as DAP with PSB seed treatment) recorded significantly higher phosphatase enzyme activity (86.09 and $86.86 \mu \mathrm{g} \mathrm{PNP} \mathrm{h}^{-1} \mathrm{~g}^{-1}$ soil). Lowest values of phosphatase enzyme activity in soil were recorded in $\mathrm{T}_{1}$ (control) treatment (23.22 and $32.04 \mu \mathrm{g}$ PNP $\mathrm{h}^{-1} \mathrm{~g}^{-1}$ soil, respectively). Significant decrease in phosphatase enzyme activity in soil was recorded due to the application of $\mathrm{P}$ levels with or without PSB seed treatment at different intervals of maize. Higher phosphatase enzyme activity is attributed to enzyme activities associated with the population of bacteria and fungi (Rao et al., 1995). The addition of both NPK+FYM, favour better root growth that contributed for higher acid phosphatase activity and it is well known that acid phosphatases are mainly root 
originated. Marinari et al., (2006) also suggested that higher soil organic carbon contents may potentially explain increased enzyme activities.

At all the stages, higher values were recorded in P levels with PSB seed treatment than only $P$ levels. This might be due to increased availability of $\mathrm{P}$ in soil due to higher application of $\mathrm{P}$, enhanced $\mathrm{P}$ availability by the mineralization of organic $\mathrm{P}$ in soil by soil microorganisms and also due to the solubilization of precipitated phosphate (Kang et al., 2002; Pradhan and Sukla, 2006 and Chen et al., 2006). Sudhir et al., (2000) also reported that the soil available $\mathrm{P}$ increased considerably due to continuous use of $\mathrm{P}$ fertilizers along with FYM. During crop growth, specific root processes, such as the release of $\mathrm{H}^{+}$ions (Hedley et al., 1982), also may be responsible for solubilizing the relatively insoluble $\mathrm{P}$ and residual $\mathrm{P}$ forms. Application of PSB helps in realizing $\mathrm{P}$ from native $P$ as well as protecting fixation of added $\mathrm{P}$ and rendering more available $\mathrm{P}$. Andrew et al., (2004) also concluded that applying manures at the rates exceeding crop removal can change soil $P$ chemistry and increase soil $\mathrm{P}$ levels. The results are in accordance with the findings of Iman and Azouni (2008) and Ramesh Chander Kuhad et al., (2011).

Available $\mathrm{P}$, microbial biomass $\mathrm{P}$ and phosphatase enzyme activity in soils under maize crop significantly increased with increasing P levels with PSB seed treatment at all growth stages. Significantly higher values were recorded with $75 \mathrm{~kg} \mathrm{P}_{2} \mathrm{O}_{5} \mathrm{ha}^{-1}$ with PSB seed treatment) compared to other treatments.

\section{References}

Andrew, N. Sharpley, Richard, W. Mcdowell, Peter and Kleinman, J. A., 2004. Amounts, forms and solubility of phosphorus in soils receiving manure. Soil Sci. Soc. Am. J., 68: 2048-2057.

Brookes, P. C., Powlson, D. C. and Jenkinson, D. S. 1982. Measurement of microbial biomass phosphorus in soil. Soil Biol. Biochem., 14: 319-329.

Chen, Y. P., Rekha, P. D., Arunshen, A. B., Lai, W. A. and Young, C. C., 2006. Phosphate solubilizing bacteria from subtropical soil and their tri-calcium phosphate solubilizing abilities. Appl. Soil Ecol., 34: 33-41.

Eivazi, Z. and Tabatabai, M. A., 1979. Phosphatase in soils. Soil Biol. Biochem., 9: 167-172.

Hedley, M. J., White, R. E. and Nye, P. H., 1982. Plant induced changes in the rhizosphere of rape (Brassica napus var. Emerald) seedlings. II. Changes in L value, soil phosphate fractions and phosphatase activity. New Phytol., 91: $45-56$.

Iman, M. and Azouni, E. L., 2008. Effect of phosphate solubilizing fungi on growth and nutrient uptake of soybean plants. $J$. Appl. Sci. Res., 4(6): 592-598.

Jackson, M. L., 1973. Soil Chemical Analysis. Prentice Hall Pvt. Ltd., New Delhi.

Kang, S. C., Hat, C. G., Lee, T. G. and Maheshwari, D. K., 2002. Solubilization of insoluble inorganic phosphates by a soil-inhabiting fungus Fomitopsis sp. PS 102. Curr. Sci., 82: $439-442$.

Logah, V., Safo, E.Y., Quansah, C. and Danso, I., 2010. Soil microbial biomass carbon, nitrogen and phosphorus dynamics under different amendments and cropping systems in semi-deciduous forest zone of Ghana. West African J. Appl. Eco., 17: 121-133.

Marinari, S., Mancinelli, R., Campiglia, E. and Grego, S., 2006. Chemical and biological indicators of soil quality in organic and conventional framing 
systems in Central Italy. Ecol. Indic. 6: 701-711.

Pradhan, N., Sukla, L. B., 2006. Solubilization of inorganic phosphates by fungi isolated from agricultural soil. African. J. Biotechnol, 5(10): 850-854.

Ramesh, C. K., Surender, S., Lata and Ajay, S., 2011. Phosphate solubilizing microorganisms, bio-augmentation, biostimulation and bio-control. Soil Biol., 28: 65-84.

Rao, C. S., Sharma, G. D. and Shukla, A. K., 1995. Spatial variation of minerals and their activity with different age groups of pine and subtropical forest soils. $J$. Boil. Ecol., 15(1): 6-16.

Sudhir, K., Chidanandappa, H. M., Srikanth, K. and Jayaprakash, S. M., 2000. Distribution of organic carbon, major and secondary nutrient elements in a red soil under long term fertilization. In: Abstracts (Volume-1) of National Seminar on Development in soil science-2000. $65^{\text {th }}$ Annual convention Dec: 27-30, 2000, at NBSS, Nagpur, IISS, IARI, New Delhi. pp-6.

\section{How to cite this article:}

Lavanya Bai, T., B.C. Dhananjaya, M. Dinesh Kumar and Gurumurthy, K.T. 2018. Effects of Fertilizer P Additions on Available P, Microbial Biomass - P and Phosphatase Enzyme Activity under Maize (Zea mays L.) in P Rich Acid Soils. Int.J.Curr.Microbiol.App.Sci. 7(09): 18271833. doi: https://doi.org/10.20546/ijcmas.2018.709.222 